\title{
SHOULD WE INCLUDE TERMS IN READABILITY FORMULAS OF SLAVONIC TEXTS?
}

\author{
Ivana Škorecová1, Aba Teleki² ${ }^{2}$ Lubomír Zelenický3
}

\begin{abstract}
In this article we show how readability depends on the number of terms. We compare two different physical-didactical texts. We explain what readability means and how readability of some didactical text can be checked. We will analyze texts of natural science. First, we use an eye tracker for measuring the time to read long terms average sized terms, and words that are not terms. We perform a cloze test. A comparison of results defined a variable of the readability formula of Slavonic physical texts.
\end{abstract}

UDC Classification: 37.02, DOI: http://dx.doi.org/10.12955/cbup.v4.768

Keywords: readability, cloze test, school book, eye tracker, term.

\section{Introduction and methods}

Readability of didactical text of natural science is not the same lite a readability of newspaper article and we can say, that readability of school text is difficult for students. It is well known that physical, biological, and mathematical texts are full of terminology or long words. The term, a technical term or terminological word denoting expressions are linguistic expression (word) that is in a particular field, craft or profession-specific, sharply defined meaning, for example: density, angle, etc. Moreover in Slavonic languages we have longer words than in English language (Škorecová, 2014).

In this article, we will show that long words and terms are important in didactical texts of natural science; though they require time to read. We define a variable of readability formula for Slavonic texts. In the next part, we choose two different didactical physical texts, each with a different number of terms. We then analyze by cloze test and show how readability depends on the number of terms.

\section{Eye Tracking}

Eye tracking is the process of measuring either the point of gaze (where one is looking) or the motion of an eye relative to the head. Cambridge dictionary (2016) define eye tracker like "the activity of studying the way that people's eyes move in order to discover what, especially in advertisements, attracts their attention". An eye tracker is a device for measuring eye positions and eye movement. Eye trackers are used in researching the visual system, in psychology, in cognitive linguistics, marketing and in study of natural sciences, too. Other methods use search coils or are based on the electrooculogram by Bulling (2009), Gneo, Schmid, Conforto, and D'Alessio (2012), and Ramiréz (2011).

\section{Readability}

Readability is what makes some texts easier to read than others. If the readability of some text high, this text is more readable than some text with low readability. It is often confused with legibility, which concerns typeface and layout. Klare in 1963 defined readability like an easy way to understand a text because of typeface and style of writing. From similar point of view Gretchen Hargis and her colleagues at IBM defined readability in 1998 like. They said that readability is an ease of reading words and sentences (DuBay, $2004 \&$ Hargis, 2000).

The creator of the SMOG readability formula G. Harry McLaughlin in 1969 say that readability depends on group of reading persons and how much this persons understand the text." This definition accent the interaction between the text and a class of readers of known characteristics such as reading skill, prior knowledge, and motivation (DuBay, 2004).

Edgar Dale and Jeanne Chall, in 1949, wrote other type of definition, more comprehensive: "The sum total (including all the interactions) of all those elements within a given piece of printed material that affect the success a group of readers have with it. The success mean, how much they understand text,

\footnotetext{
${ }^{1}$ Ivana Škorecová, Department of physics, Constantine the Philosopher University in Nitra, Slovakia, ivana.skorecov@ukf.sk

${ }^{2}$ Aba Teleki, Department of physics, Constantine the Philosopher University in Nitra, Slovakia, ateleki@ukf.sk

${ }^{3}$ Lubomír Zelenický, Department of physics, Constantine the Philosopher University in Nitra, Slovakia, lzelenicky@ukf.sk
} 
read text at an optimal speed, and find main idea of text" (DuBay, 2004, The Principles of Readability).

\section{Eye Tracking in Study of Readability}

We used eye tracker to analyze part of readability of physical text. It is well known that analysis of readability components is very difficult. It depends on language and structure. It is known that analyzing poetical text is not the same as didactical or physical text. One question about analyzing physical text is: "Students give more attention of read long words? Long word is word with more than six letters. We try to offer answer on this question and our results we will present in next part. We choose didactical text and then we choose 15 areas of interest" (Gneo et al., 2012).

Table 1: Areas of interest (AOI) and words with number of letters

\begin{tabular}{|l|l|l|}
\hline AOI & Word* & Number of letters \\
\hline 2 & $\begin{array}{l}\text { Termoreceptorami } \\
\text { thermoreceptors }\end{array}$ & $16^{* * *}$ \\
\hline 3 & Zmysl - sense & 5 \\
\hline 4 & Dotyku - touch & 6 \\
\hline 5 & Zakończenia -finish & $11^{* * *}$ \\
\hline 6 & Receptory bóli - pain receptors & $13 * * *$ \\
\hline 7 & Receptory - receptors & $9 * *$ \\
\hline 8 & $\begin{array}{l}\text { Termoreceptory } \\
\text { thermoreceptors }\end{array}$ & $14 * * *$ \\
\hline 9 & Twojej - your & 6 \\
\hline 10 & Ucisk - pressure & 5 \\
\hline 11 & Wraźliwe -sensitive & $8 * *$ \\
\hline 12 & Zimny - cold & 5 \\
\hline 13 & Chlodniej - cooler & $9 * *$ \\
\hline 14 & Ruchy - movements & 5 \\
\hline$*$ Short words, words with more than 6 letters and less than $10^{* *}$, words with more than 10 letters \\
$* * *$. & \multicolumn{2}{|l}{} \\
\hline \multicolumn{2}{|l|}{ Source: Škorecová and Teleki (2015) } \\
\hline
\end{tabular}

Figure.1: Dwell Time (min) of all students of all AOI

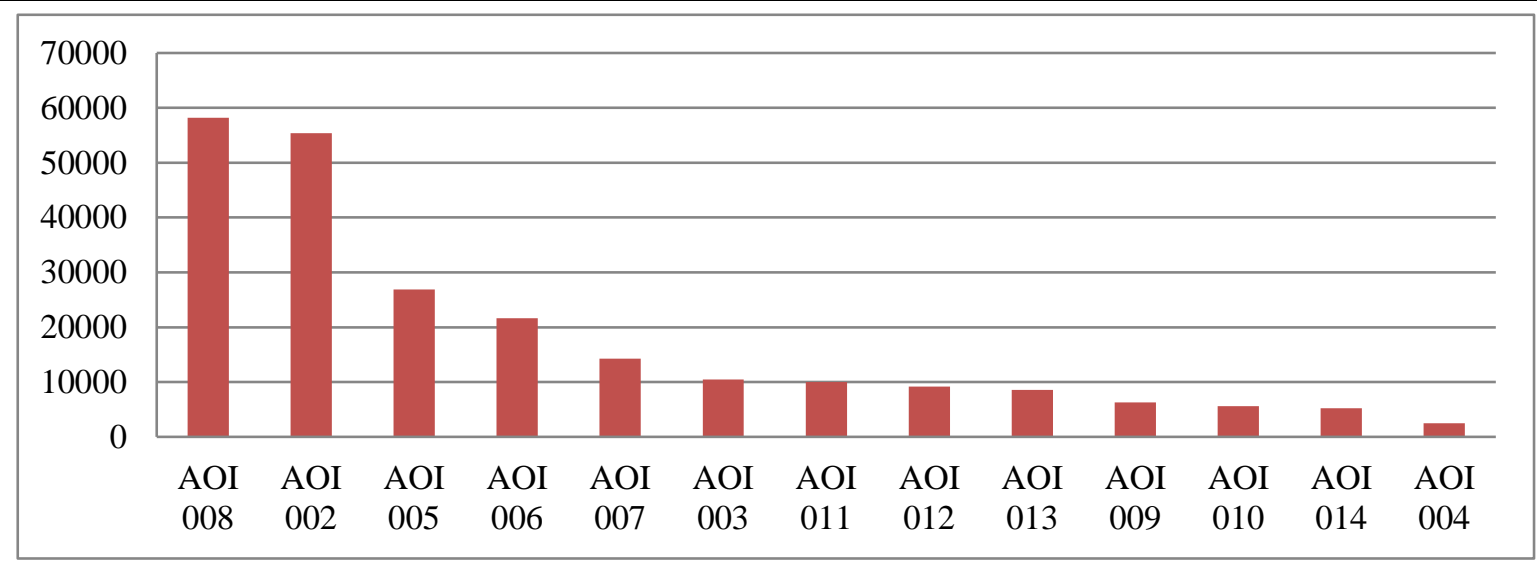

Source: Škorecová and Teleki (2015)

We noted that student spent a long period of time reading words with more than 10 letters. Analyzing the attention of interest (AOI, see Table 1), AOI-2, $-5,-6$, and -8 . AOI-7 was remarkable, because they were terms. Our goal was to include terms into the readability formula. Figure 1 confirms our hypothesis. 
The length of time spent for each student to read these areas of interest are shown in Figure 2.

Figure 2: Dwell Time (min) of each student and partial dwell time of reading areas of interest

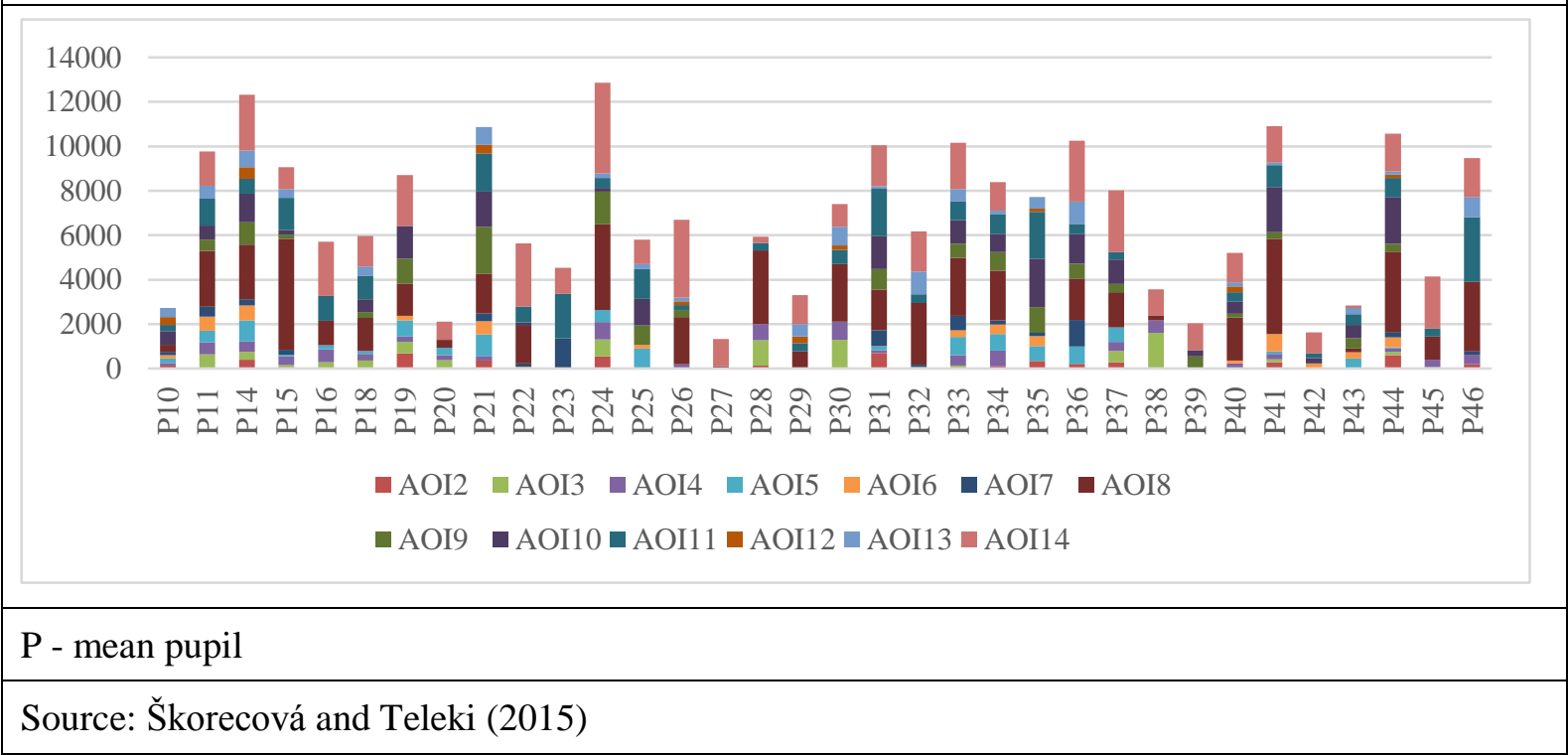

In Figure 2, the AOI-2 and AOI-8 are shown as orange and dark brown color and in the Figure 5 is comparision of the dwell time of AOI 2 and AOI 8 . We conclude that each student spent a long period of time to read this text, apart from students P20, P27, and P42. In our opinion these students did not read the text attentively. Because of this, we chose to exclude these three students from the statistics.

\section{Areas of interest (AOI)}

AOI-3 (Figure 3.) is word 'zmysl' with five letters. It is a short word, but is the first word of the title. Thus, we expected this word would require more attention of the students. However, this word was shorter than the next word 'dotyku', which would take more attention. From another point of view 'zmysl' is a term, so we plan to include this type of word into readability formula.

AOI-5 (Figure 4.) is word 'zakończenia' with 11 letters. It is a long word, but not a term. More than $50 \%$ of students spent more than $500 \mathrm{~min}$ to read this word. Thus, this type of word should be included into the readability formula.

Figure 3: Dwell time (min) of areas of interest-3 of all students

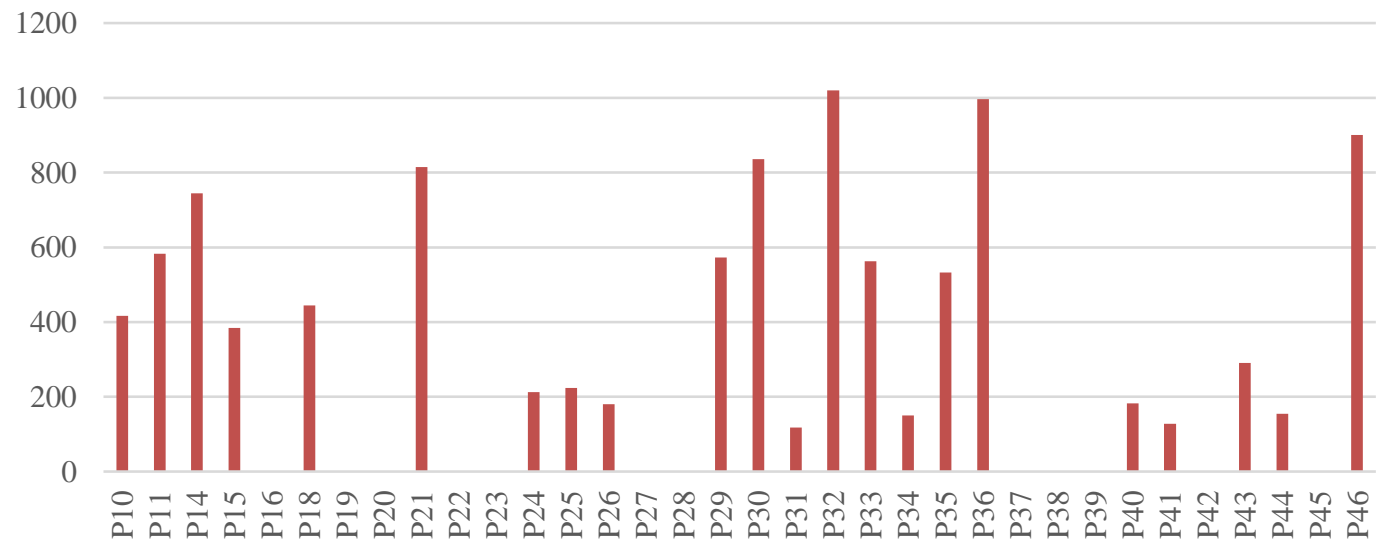

Source: Škorecová and Teleki (2015) 


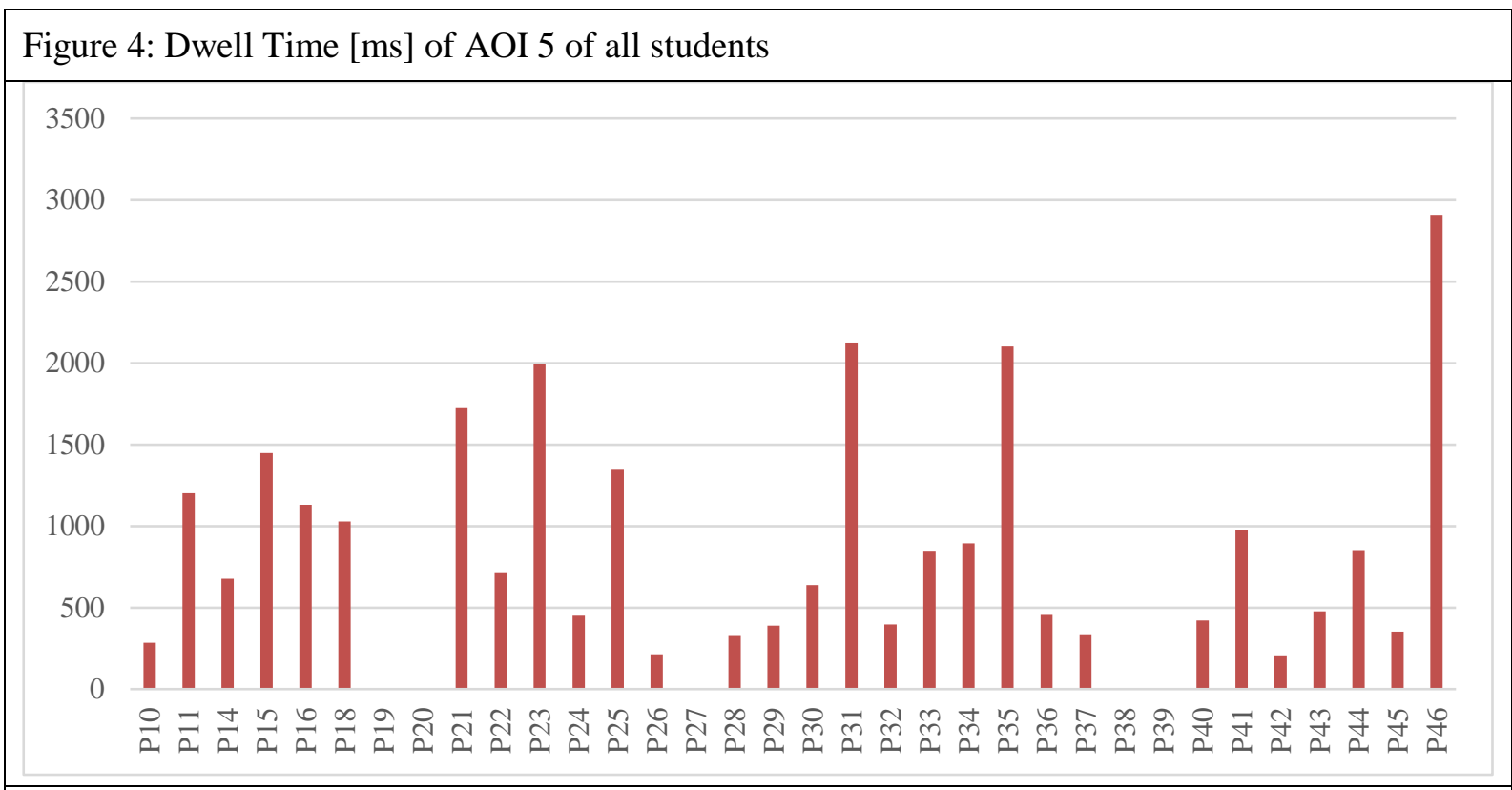

Source: Škorecová and Teleki (2015)

\section{Comparison of AOI-2 and AOI-8}

The results show AOI-2 and AOI-8 are similar. In these areas, the words 'termoreceptorami' and 'termoreceptory' occur.

In conference some persons said, that where a student reads the same word a second time or more, they need less time to read the word. We can't accept this idea without some measure, Figure 4 shows the results of our measurement.

Figure 5: Dwell time (min) of areas of interest (AOI) 2 and AOI- 8 of all students

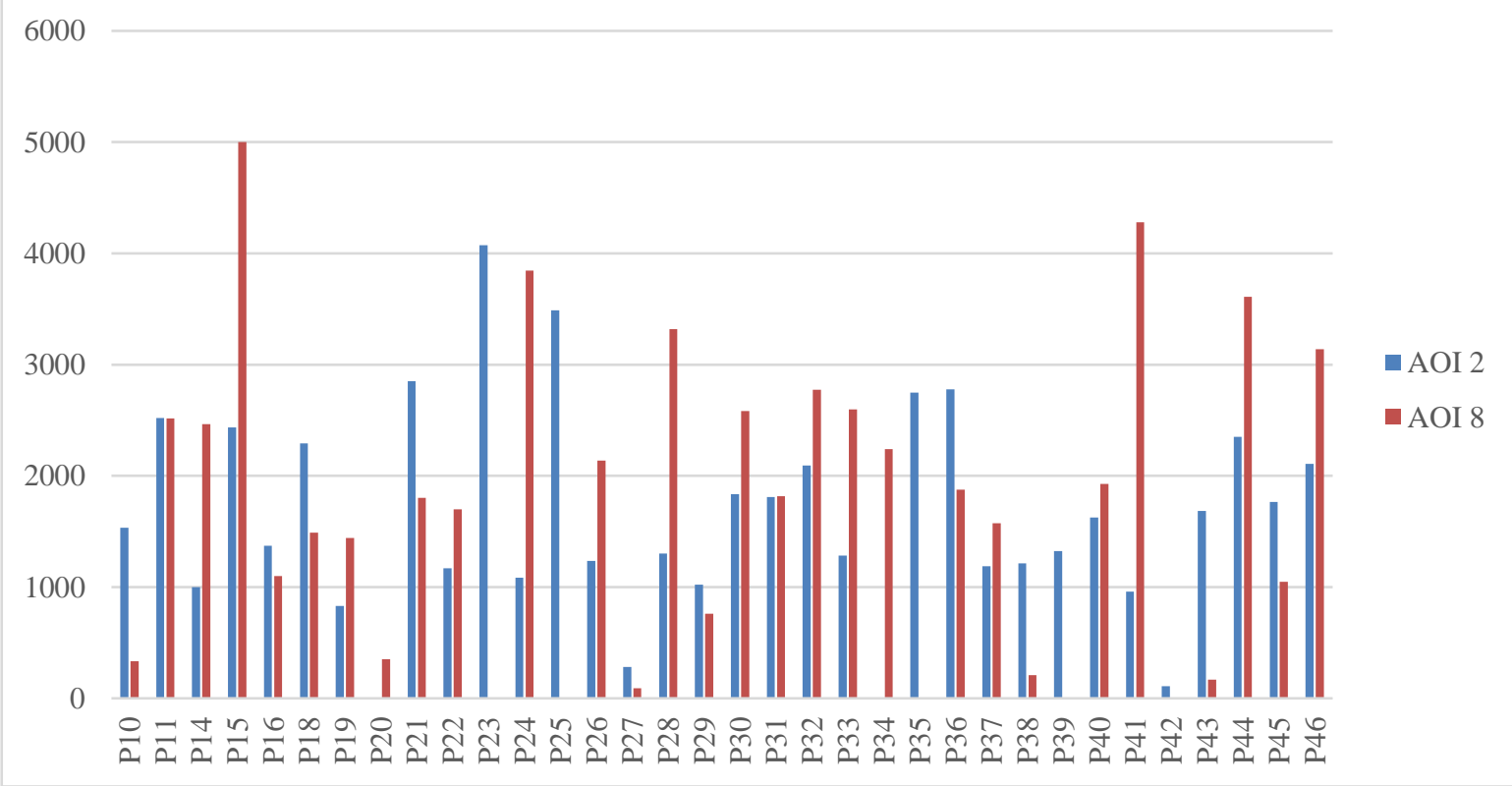

Source: Škorecová and Teleki (2015)

In the group of 34 students, two students needed equal time and 13 needed more time to read AOI-2, compared to that for AOI-8. However, 19 students needed more time to read AOI-8. In some cases, namely for student, P 15, P 28, and P 41, the time needed was more than three times greater. 
Therefore, we expect that the frequency of long words and terms are important from the view point of readability. In addition, where a word is mentioned in the text two to four times, to the word should be included into the formula to attract the attention of the reader.

\section{Readability of Physical Didactical Text}

In this part, we chose two didactical physical texts. Both are about the same topic, but contain a different number of terms. We analyse the readability using the method of cloze tests (Klare,1984; Šrajerová \& Gavora, 2008, p. 209).

The first text is from the textbook for high school students and second, from a textbook for undergraduate students, as follows:

1. JÁN PIŠÚT, VÁCLAV FREI Et al.- Physics for $4^{\text {th }}$ grade of high schol (Pišút, 1993)

2. R. P. FEYNMAN, R. B. LEIGHTON, M. SANDS: The Feynman Lectures on Physics in Slovak language (Feynman, 1986)

\section{The Pišút's Text}

This text (Pišút, 1993, pp. 15-17) is about reflection and refraction of light, including the refractive index. We highlighted the physical terms in yellow shading.

Table 2: Statistical analyze of the Pišút 's text

\begin{tabular}{|l|l|}
\hline Syllable Count & 896 \\
\hline Word Count & 528 \\
\hline Sentence Count & 38 \\
\hline
\end{tabular}

Source: Author

Figure 6: Number of terms

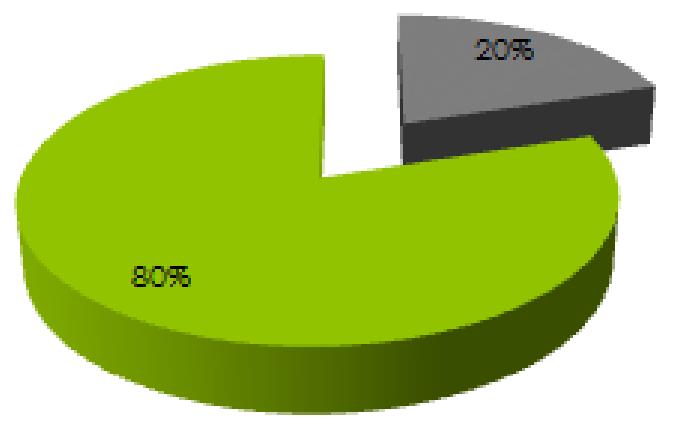

Source: Author

\section{The Feynmann's Text}

This text (Feynman, 1986, p.8-10) is about reflection and refraction of light, also. We highlighted physical terms also.

Table 3: Statistics of the Feynmann 's text

\begin{tabular}{|l|c|}
\hline Syllable Count & 870 \\
\hline Word Count & 495 \\
\hline Sentence Count & 43 \\
\hline
\end{tabular}

Source: Škorecová, 2016 


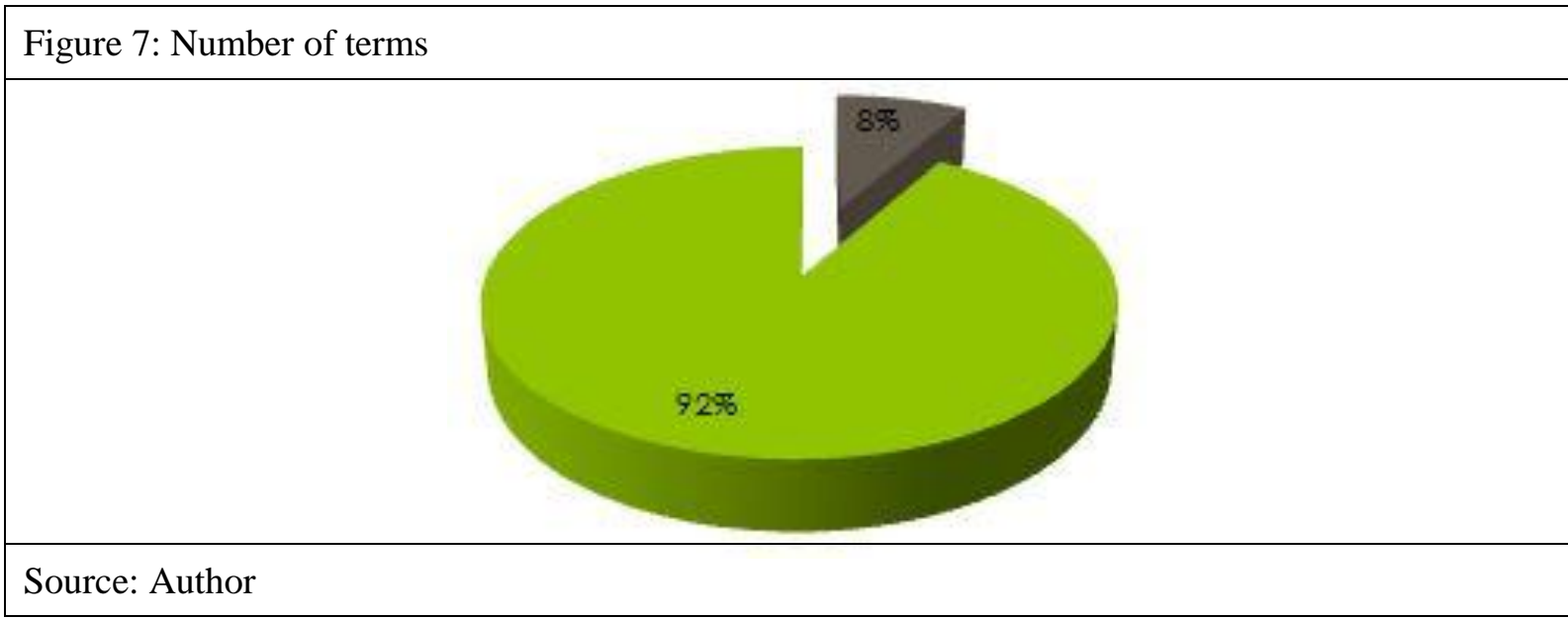

\section{Cloze Test}

We analyzed the readability using the cloze test, which is a test of the ability to comprehend text in which the reader has to supply the missing words that have been removed from the text at regular intervals (Dubay, 2004; Šrajerová \& Gavora, 2009). We performed the test on results from a group of 150 students. The 'right answer' in the cloze test was deemed to be the same word as in the original text, or its synonym as well as without grammatical error.

\begin{tabular}{|l|l|l|l|l|}
\hline Figure 8. Results of cloze test & \\
\hline Source: Author & & \\
\hline
\end{tabular}

The orange bars in Figure 8 presents the readability of the first text (Pišút), expressed by the success of students, based on the cloze test. Most students had success between 30 and $40 \%$. The red areas in Figure 8 show the readability of the second text (Feynman) and most students had success between 50 and $60 \%$.

A maximum of this function lying on the right side of the graph, indicates the text is more readable. Thus, the second text (Feynman) is shown as more readable than the first (Figure 8).

\section{Definition of Variable}

We suggest there is a need to include terms (short and long) into the readability formula, based on the results of this study.. These words (terms) required a greater length of time for reading. Therefore, long 'non-term', for example: your, put, take (those words are longer in Slavonic languages) words need inclusion into the readability formula, also. Including terms is the difference between the Flesch Kinkaid readability formula and new readability formula for Slavic didactical texts. 


\section{Conclusion}

In accordance with our expectations, long words and terms need inclusion in a readability formula for Slavic didactical texts. A text of natural science is difficult text containing numerous terms and where the author uses several terms and long words, the text will become unreadable for $90 \%$ students. The eye tracking method showed how a long word or term require attention. Long words and terms need to be included in a readability formula for Slavic texts. We showed, that higher frequency of terms resulted in the text being less readable and that Feynman's texts was more readable than Pišút's. This method allows teachers, authors, or other individuals to check text for readability. This method takes less time to perform than the cloze test method. In a short time, the program provided a graph of the results.

\section{References}

Bulling, A., Ward, J. A., Gellersen, H., \& Tröster, G. (September, 2009). Eye Movement Analysis for Activity Recognition, Proc. of the 11th International Conference on Ubiquitous Computing (UbiComp 2009), pp. 41-50, Orlando, United States.

Cambride dictionary (2016). http://dictionary.cambridge.org/dictionary/english/eye-tracking.

Dubay, W. H. (2004). The Principles of Readability. Costa Mesa, California, pp. 73., http://www.impact-

information.com/impactinfo/readability02.pdf

Feynman, R.P. (1986). preklad: J. Foltin. Feynmanove prednášky z fyziky 2. Bratislava: Alfa.

Gneo, M., Schmid, M., Conforto, S., \& D’Alessio, T. (2012). "A free geometry model-independent neural eye-gaze tracking system". Journal of NeuroEngineering and Rehabilitation 9 (1): 82.

Hargis, G. (2000). "Readability and computer documentation.” ACM journal of computer documentation 24, no. 3:122-131.

Klare, G. R. (1984). Handbook of Reading Research, volume 1, chapter 22, pages.

Pišút, J., Frei, V., Fuka, J., Lehotský, D., Široký, J., Tomanová, E., \& Vanýsek, V. (1993). Fyzika pre 4. ročník gymnázia [Physics for $4^{\text {th }}$ grade on high school]. Slovenské pedagogické nakadatel'stvo Bratislava.

Ramiréz, A. (2011). Eye-tracking: una técnica se seguimiento de la miradautilizada en la validación de unidades de aprendizaje, Instituto Tecnológico de Costa Rica.

Šrajerová, H., \& Gavora, P. (2009). Porozumenie textu zist'ovane cloze-testom vzhl'adom k obtiažnosti učebneho textu.[ Determined readability cloze-test due to the difficulty of teaching texts.] Slovensky jazyk a literatura v škole 55.

Škorecová, I., \& Teleki, A. (2015). How use eye tracking during didactical analyse of didactical physical text, in: $21^{\text {st }}$ conference of Slovak physicists 7.-10.9.2015, Košice, Equilibria s.r.o, ISBN: 978-80-971450-7-1.

Škorecová, I (2014). Existuje univerzálna metrika na určenie čitatel'nosti textu? [Does exist universal readability formula?], in print in Zborník z konferencie DidFyz 2014.

Škorecová, I. (2016). Correlation between readability and number of terms in physical-didctical texts. Accepted in book of papers of Autumn Conference for PhD students in Nitra. 